\title{
Efektifitas Praperadilan dalam Sistem Peradilan Pidana Anak di Indonesia
}

\author{
Syachdin ${ }^{1}$ \\ Fakultas Hukum Universitas Tadulako, \\ Jln. Soekarno Hatta Km. 9 Palu - Sulawesi Tengah, \\ Telp. (0451) 422611, Fax. (0451) 422844 \\ Email:syachdin@mail.com \\ Joko Jumadi \\ Fakultas Hukum Universitas Mataram, \\ Jln. Majapahit No. 62 Mataram 83125, \\ Telp. (0370) 633035, Fax. 626954 \\ Email: jokojumadi@gmail.com
}

\begin{abstract}
ABSTRAK
Masa penahanan anak dalam tahapan penyidikan dengan perpanjangan maksimal adalah 15 hari, sementara penahanan untuk anak dalam tahapan penuntutan adalah 10 hari, artinya masa dimana bisa diajukan praperadilan adalah total 25 hari dari mulai dilakukan penahanan. Melihat persesuaian antara waktu dapat diajukannya parperadilan dalam UU SPPA, dilihat dari masa penahanan, dengan fakta empiris waktu acara praperadilan, maka bisa dipastikan akan terjadi kendala serius dalam pengajuan praperadilan dalam kasus-kasus anak. Belum lagi fakta yang menunjukkan bahwa dengan menelisik proses pengajuan permohonan praperadilan, keberadaan advokat rupanya berpengaruh besar pada penggunaan mekanisme praperadilan. Situasi ini dapat dilihat dalam komposisi pengajuan permohonan praperadilan antara yang diwakili advokat dengan yang tidak. kedudukan lembaga praperadilan dengan adanya asas Lex Specialis Derogat Legi Generalis memiliki kedudukan hukum umum karena tidak diatur secara khusus dalam SPPA mengenai lembaga praperadilan, maka hubungan antara SPPA dengan KUHAP merupakan Lex Specialis Derogat Legi Generalis dari KUHAP. Dalam mengadili perkara anak penggunaan pengaturan Undang Undang SPPA didahulukan dari pengaturan yang diatur dalam KUHAP. Namun jika tidak diatur di dalam Undang Undang SPPA, baru digunakan pengaturan yang diatur dalam KUHAP yang merupakan ketentuan hukum umumnya. Jadi, Lembaga Praperadilan berlaku juga pada proses penyelesaian perkara tindak pidana anak karena tidak diatur secara khusus dalam SPPA.
\end{abstract}

1 Dosen Fakultas Hukum Universitas Tadulako.

2 Dosen Fakultas Hukum Universitas Mataram. 


\section{A. PENDAHULUAN}

Setelah hampir 15 tahun berlaku akhirnya Undang-Undang nomor 3 tahun 1997 digantikan dengan Undang-Undang nomor 11 tahun 2012 tentang system peradilan pidana anak. Perubahan UU No. 3 tahun 1997 tentang Pengadilan Anak menjadi UU No. 11 tahun 2012 tentang Sistem Peradilan Pidana Anak disebabkan adanya kebutuhan hukum masyarakat terkait ketidak efektifan sistem peradilan pidana anak untuk memperoleh keadilan, dan menurunkan jumlah tindak pidana dan residivisme anak.

Salah satu persoalan penting yang menjadi alasan perubahan UU No. 3 tahun 1997 adalah masih banyaknya anak-anak yang harus menjalani perampasan kemerdekaan dikarenakan dilakukan penahanan selama proses penyidikan, penuntutan dan/atau pemeriksaan sidang pengadilan. Masalah penahanan terhadap anak merupakan masalah krusial di Indonesia. Setidaknya ada dua hal yang harus diperhatikan dalam UU SPPA terkait pengawasan dan mekanisme komplain terhadap upaya paksa penahanan.

Masa penahanan anak dalam tahapan penyidikan dengan perpanjangan maksimal adalah 15 hari, sementara penahanan untuk anak dalam tahapan penuntutan adalah 10 hari, artinya masa dimana bisa diajukan praperadilan adalah total 25 hari dari mulai dilakukan penahanan. Melihat persesuaian antara waktu dapat diajukannya parperadilan dalam UU SPPA, dilihat dari masa penahanan, dengan fakta empiris waktu acara praperadilan, maka bisa dipastikan akan terjadi kendala serius dalam pengajuan praperadilan dalam kasus-kasus anak. Belum lagi fakta yang menunjukkan bahwa dengan menelisik proses pengajuan permohonan praperadilan, keberadaan advokat rupanya berpengaruh besar pada penggunaan mekanisme praperadilan. Situasi ini dapat dilihat dalam komposisi pengajuan permohonan praperadilan antara yang diwakili advokat dengan yang tidak. Melihat dari fakta tersebut, sangat menarik kiranya persoalan praperadilan dalam perkara anak yang berkonflik dengan hukum dikaji secara lebih mendalam melalui sebuah penelitian yang dalam penelitian ini hanya dibatasi pada permasalahan Bagaimanakah efektifitas praperadilan dalam sistem peradilan pidana anak di Indonesia?

\section{B. PEMBAHASAN}

Sistem hukum acara pidana di Indonesia, pada dasarnya telah mengakui mekanisme komplain terhadap upaya paksa dari aparat penegak hukum, khususnya terkait dengan penangkapan dan penahanan, yang terwujud melalui lembaga praperadilan. Upaya ini dihadirkan dengan maksud sebagai ruang komplain terhadap perampasan kebebasan sipil seseorang, yang mungkin dilakukan secara sewenang-wenang oleh aparat penegak hukum.

Mengenai mekanisme ini, Pasal 1 angka 10 KUHAP menyebutkan: Praperadilan adalah wewenang pengadilan negeri untuk memeriksa dan memutus menurut cara yang diatur dalam UndangUndang ini, tentang:

a. sah atau tidaknya suatu penangkapan dan atau penahanan atas permintaan tersangka atau keluarganya atau pihak lain atas kuasa tersangka;

b. sah atau tidaknya penghentian penyidikan atau penghentian penuntutan atas permintaan demi tegaknya hukum dan keadilan; c. permintaan ganti kerugian atau rehabilitasi oleh tersangka atau keluarganya atau pihak lain atas 
kuasanya yang perkaranya tidak diajukan ke pengadilan.

Ketentuan mengenai praperadilan, khususnya terkait dengan hukum acaranya, diatur secara terbatas di dalam Pasal 77 hingga Pasal 83 KUHAP. Dalam putusan Mahkamah Konstitusi (MK) mengenai uji materi atas KUHAP, MK menyatakan bahwa praperadilan merupakan suatau terobosan baru dalam sistem peradilan pidana Indonesia. MK menjelaskan, Herziene Inlandsche Reglement (H.I.R) yang menganut sistem inquisitoir, tidak mengenal adanya lembaga ini.

Dalam sistem inquisitoir, tersangka atau terdakwa ditempatkan dalam pemeriksaan sebagai objek yang mungkin mengalami perlakuan sewenang-wenang penyidik terhadap tersangka. Sehingga, sejak pemeriksaan pertama di hadapan penyidik, tersangka sudah dianggap bersalah. Sedangkan KUHAP telah menempatkan tersangka/terdakwa tidak lagi sebagai objek pemeriksaan, namun sebagai subjek manusia yang mempunyai harkat, martabat, dan kedudukan yang sama di hadapan hukum.

Praperadilan dimaksudkan sebagai mekanisme kontrol terhadap kemungkinan tindakan sewenang-wenang penyidik atau penuntut umum dalam melakukan penangkapan, penggeledahan, penyitaan, penyidikan, penuntutan, penghentian penyidikan dan penghentian penuntutan, baik yang disertai dengan permintaan ganti kerugian dan/atau rehabilitasi atau pun tidak.

Lebih jauh, praperadilan bertujuan menegakkan dan memberikan perlindungan hak asasi manusia (HAM) tersangka/terdakwa dalam pemeriksaan penyidikan dan penuntutan. Mekanisme ini dipandang sebagai bentuk pengawasan secara horizontal terhadap hak-hak tersangka/terdakwa dalam pemeriksaan pendahuluan.

Menurut M. Yahya Harahap, Praperadilan merupakan hal baru dalam dunia peradilan indonesia. Praperadilan merupakan salah satu lembaga baru yang diperkenalkan oleh KUHAP di tengahtengah kehidupan penegakan hukum. Praperadilan dalam dalam KUHAP, ditempatkan dalam Bab X, Bagian Kesatu, sebagai salah satu bagian ruang lingkup wewenang mengadili bagi Pengadilan Negeri. ${ }^{1}$

Ditinjau dari segi struktur dan susunan praperadilan, praperadilan bukan lembaga pengadilan yang berdiri sendiri. Bukan pula sebagai instansi tingkat peradilan yang mempunyai wewenang memberi putusan akhir atas suatu kasus peristiwa pidana.

Praperadilan hanya suatu lembaga baru yang menurut $M$. Yahya Harahap, Lembaga yang mempunyai ciri dan eksistensinya sebagai berikut $:^{2}$

1. Berada dan merupakan kesatuan yang melekat pada pengadilan negeri, dan sebagai lembaga pengadilan, hanya dijumpai pada tingkat pengadilan negeri sebagaimana satuan tugas yang tidak terpisah dari pengadilan negeri;

2. Dengan demikian, praperadilan bukan berada di luar atau di samping maupun sejajar dengan pengadilan negeri, tapi merupakan divisi dari pengadilan negeri;

3. Administratif yustisial, personil, peralatan, dan finansial bersatu dengan pengadilan negeri, dan berada dibawah pimpinan serta pengawasan dan pembinaan ketua pengadilan negeri.

4. Tata laksana fungsi yustisialnya merupakan bagian dari fungsi yustisial pengadilan negeri itu sendiri.

Dalam Pasal 1 butir 10 KUHAP,

${ }^{1}$ Harahab, Op.Cit., hlm. 1. $\quad{ }^{2}$ Ibid., 
menegaskan pengertian Praperadilan adalah wewenang pengadilan negeri untuk memeriksa dan memutus menurut cara yang diatur dalam Undang-Undang ini tentang :

1. Sah atau tidaknya suatu penangkapan dan atau penahanan atas permintaan tersangka dan keluarganya atau pihak lain atas kuasa tersangka;

2. Sah atau tidaknya penghentian penyidikan atau penghentian penuntutan atas permintaan demi tegaknya hukum dan keadilan;

3. Permintaan ganti kerugian atau rehabilitasi oleh tersangka atau keluarganya atau pihak lain atas kuasanya yang perkaranya tidak dilanjutkan ke pengadilan.

Pengertian yang dirumuskan dalam Pasal 1 butir 10, dipertegas dalam Pasal 77 KUHAP yang menjelaskan : Pengadilan Negeri berwenang untuk memeriksa dan memutus, sesuai dengan ketentuan yang diatur dalam UndangUndang ini tentang :

1. Sah atau tidaknya penangkapan, penahanan, penghentian penyidikan atau penghentian penuntutan;

2. Ganti kerugian dan atau rehabilitasi bagi seseorang yang perkara pidananya dihentikan pada tingkat penyidikan dan penuntutan.

Dalam perkembangannya Pasal 1 angka 10 juncto Pasal 77 tentang Lembaga Praperadilan yang terdapat pada BAB X "Wewenang Pengadilan untuk Mengadili “, Bagian Kesatu (I) "Praperadilan" yang terdapat beberapa Pasal yang mengatur tentang Praperadilan mulai dari Pasal 77 sampai dengan Pasal 83 KUHAP sehingga terdapat 6 Pasal yang mengatur tentang Praperadilan dalam KUHAP. Dalam perkembangannya KUHAP sejak tahun 1981 sampai dengan 2016 pernah diajukan beberapa kali Pengujian Undang-Undang (Judicial Review) kepada Mahkamah Konstitusi terhadap Pasal-Pasal yang terkait dengan Praperadilan yang ada di dalam KUHAP. Ada dua Putusan Mahkamah Konstitusi yang mengabulkan permohonan pengujian terhadap Pasal Praperadilan yang ada dalam KUHAP yang membuat pengaturan terhadap praperadilan yang ada dalam KUHAP berubah atau tidak memiliki kekuatan hukum.

Putusan Mahkamah Konstitusi Nomor 65/PUU-IX/2011 Pada tahun 2011 ada seorang Anggota Polri yang bernama Tjetje Iskandar, mengajukan permohonan dengan surat permohonan bertanggal 16 september 2011, berdasarkan Akta Penerimaan Berkas Permohonan Nomor 327/PAN.MK/2011 yang dicatat dalam Buku Registrasi Perkara Konstitusi dengan Nomor 65/PUU-IX/2011 pada tanggal 26 September 2011 yang telah diperbaiki dan diterima kepaniteraan mahkamah pada tanggal 18 oktober 2011. ${ }^{3} \mathrm{Pada}$ pokok permohonannya mengajukan pengujian terhadap Pasal 83 ayat (1) dan ayat (2) KUHAP yang berbunyi :

(1)"Terhadap putusan pra peradilan dalam hal sebagaimana dimaksud dalam Pasal 79, Pasal 80 dan Pasal 81 tidak dapat dimintakan banding";

(2) "Dikecualikan dari ketentuan ayat (1) adalah putusan pra peradilan yang menetapkan tidak sahnya penghentian penyidikan atau penuntutan, yang untuk itu dapat dimintakan putusan akhir ke Pengadilan Tinggi dalam daerah hukum yang bersangkutan";

Dalam pertimbangan hukumnya, Hakim Mahkamah Konstitusi dalam Putusan Mahkamah Konstitusi Nomor

3 Mahkamah Konstitusi, Putusan Nomor 65/PUUIX/2011. hlm. 2. 
65/PUU-IX/2011 terhadap pengujian Pasal 83 ayat (1) dan ayat (2) KUHAP menyampaikan beberapa hal dalam menjatuhkan putusan terkait permohonan yang diajukan oleh pemohon. Pertama, menurut Mahkamah Konstitusi, pemeriksaan permohonan praperadilan yang diatur dalam KUHAP dilakukan secara cepat. Pemeriksaan praperadilan dilakukan paling lambat tiga hari setelah permohonan diajukan, hakim tunggal yang telah ditetapkan mengadili praperadilan yang bersangkutan sudah harus menetapkan hari sidang. Dalam waktu paling lama tujuh hari, hakim praperadilan sudah harus menjatuhkan putusan. Ketentuan pasal 82 ayat (1) KUHAP menentukan bahwa acara pemeriksaan praperadilan harus dilakukan secara cepat. Pasal 82 ayat (1) KUHAP menentukan bahwa apabila suatu perkara sudah mulai diperiksa oleh pengadilan negeri, sedangkan permintaan mengenai praperadilan belum selesai, maka praperadilan tersebut gugur. ${ }^{4} \mathrm{Kedua}$, menurut Mahkamah Konstitusi acara praperadilan adalah acara cepat, sehingga seharusnya tidak dapat dimohonkan pemeriksaan banding. Meskipun demikian, Pasal 83 ayat (2) KUHAP menentukan, "Dikecualikan dari ketentuan ayat (1) adalah putusan praperadilan yang menetapkan tidak sahnya penghentian penyidikan atau penuntutan yang untuk itu dapat dimintakan putusan akhir ke pengadilan tinggi dalam daerah hukum yang bersangkutan". ${ }^{5}$ Ketiga, menurut Mahkamah Konstitusi bahwa pasal 83 ayat (2) KUHAP bertentangan dengan pasal 27 ayat (1) dan pasal 28D ayat (1) Undang-Undang Dasar Negara Republik Indonesia Tahun 1945. Hal tersebut dikarenakan pasal 83 ayat (2) KUHAP tidak mempersamakan kedudukan warga negara di dalam hukum dan pemerintahan serta tidak memberikan kepastian hukum yang adil. Pasal 83 ayat (2) KUHAP memperlakukan secara berbeda antara tersangka/terdakwa di satu pihak dan penyidik serta penuntut umum di pihak lain dalam melakukan upaya hukum banding terhadap putusan praperadilan. Ketentuan demikian tidak sesuai dengan filosofi diadakannya lembaga praperadilan yang justru menjamin hak-hak tersangka/terdakwa sesuai dengan harkat dan martabatnya sebagai manusia. ${ }^{6}$

Berdasarkan pertimbangan hukum diatas, kemudian Mahkamah Konstitusi memberikan dua alternatif yang dimungkinkan dapat memperlakukan hal yang sama antara tersangka atau terdakwa serta penyidik dan penuntut umum. Dua alternatif tersebut yaitu memberikan hak kepada tersangka/terdakwa untuk mengajukan permohonan banding atau menghapuskan hak banding untuk penyidik dan penuntut umum. Dari kedua alternatif tersebut, kemudian Mahkamah Konstitusi mengambil alternatif yang kedua yaitu menghapuskan hak banding bagi penyidik dan penuntut umum terkait dengan praperadilan. Alternatif yang kedua ini diambil karena dianggap memberikan perlakuan yang adil bagi kedua belah pihak. ${ }^{7}$

Dalam Amar putusannya pada Putusan Mahkamah Konstitusi Nomor 65/PUU-IX/2011 tersebut mengabulkan sebagian permohonan pemohon dalam putusannya yang menyatakan "Pasal 83 ayat (2) Undang-Undang Nomor 8 Tahun 1981 tentang Hukum Acara

\begin{tabular}{ll}
\hline${ }^{4}$ Ibid., hlm. 29. & ${ }^{6}$ Ibid., hlm. 30. \\
${ }^{5}$ Ibid., & ${ }^{7}$ Ibid., \\
\hline
\end{tabular}


Pidana (Lembaran Negara Indonesia Tahun 1981 Nomor 76, Tambahan Lembaran Negara Republik Indonesia Nomor 3209) bertentangan dengan Undang-Undang Dasar Negara Republik Indonesia Tahun 1945 dan Pasal 83 ayat (2) Undang-Undang Nomor 8 Tahun 1981 tentang Hukum Acara Pidana (Lembaran Negara Indonesia Tahun 1981 Nomor 76, Tambahan Lembaran Negara Republik Indonesia Nomor 3209) tidak mempunyai kekuatan hukum mengikat. $^{8}$

Salah satu dampak yang ditimbulkan setelah adanya Putusan Mahkamah Konstitusi Nomor 65/PUUIX/2011, terlihat pada permohonan praperadilan dalam kasus penetapan status tersangka Komjen Budi Gunawan oleh KPK dalam kasus tindak pidana gratifikasi, Putusan Praperadilan Nomor 04/Pid.Prap/2015/PN.Jkt.Sel. tidak dapat diajukan upaya hukum banding maupun kasasi untuk membatalkan putusan yang telah dijatuhkan tersebut. Kasus ini menjadi kasus yang banyak dibicarakan oleh masyarakat Indonesia dan menjadi isu hangat dalam dunia hukum. Hal ini dikarenakan dalam kasus praperadilan tersebut pihak Komjen Budi Gunawan selaku pemohon praperadilan melawan pihak termohon KPK, mengajukan permohonan atau gugatan praperadilan yang pokok permohonannya adalah penetapan status tersangka Komjen Budi Gunawan dalam kasus gratifikasi yang dianggap melanggar Undang-Undang dan dianggap tidak sah.

$$
\text { Jika dicermati pengajuan }
$$

permohonan perkara praperadilan tentang tidak sahnya penetapan status tersangka dan permohonan penghentian penyidikan atas diri pemohon yaitu Komjen Budi Gunawan, bukanlah perkara yang dapat diajukan dalam sidang praperadilan sebagaimana tercantum dalam Pasal 1 Angka 10 Jo Pasal 77 KUHAP. Namun faktanya dalam kasus ini permohonan praperadilan pihak Komjen Budi Gunawan tetap diperiksa dipersidangan dan dikabulkan sebagian. Dalam beberapa tahun terakhir pengajuan permohonan prapreradilan yang serupa dengan kasus praperadilan Komjen Budi Gunawan yang dapat dikatakan merupakan putusan yang dibuat diluar kewenangan hakim dalam sidang praperadilan sebagaimana tercantum dalam Pasal 1 Angka 10 Jo Pasal 77 KUHAP juga pernah terjadi antara lain : 1. Putusan Nomor 04/Pid.Prap/2010/PN.Jkt.Sel. dengan pemohon yaitu Toto Chandra, manager Permata Hijau Group dalam kasus faktur fiktif pada ta-hun 2009 dengan hakim tunggal yang dipimpin oleh Hakim Muhammad Razzad yang amar putusannya menyatakan bahwa penyidikan terhadap pemohon harus dihentikan.

2 38/Pid.Prap/2012/PN.Jkt-Sel dengan pemohon yaitu Bachtiar Abdul Fatah, manager PT Chevron Pacific Indonesia (PT. CPI) dalam kasus korupsi bioremediasi dengan hakim tunggal yang dipimpin oleh Hakim Suko Harsono yang amar putusannya menyatakan bahwa penetapan status tersangka pada diri pemohon adalah tidak sah. ${ }^{9}$

Berdasarkan dalam kasus Budi Gunawan tersebut yang mengajukan permohonan praperadilan dengan pokok permohonan atas penetapan tersangka yang telah dilakukan oleh penyidik KPK. Sah atau tidaknya penetapan tersangka oleh penyidik bukan merupakan salah satu objek praperadilan yang diatur dalam pasal 77 KUHAP.

\footnotetext{
${ }^{8}$ Ibid., hlm. 31
}

${ }^{9}$ http://news.detik.com/berita/2818530/catat-ini-2-voniskontroversial-pn-jaksel-di-kasus-praperadilan/2, diakses pada tanggal 12 Mei 2016 Pukul 17.00 WITA. 
Putusan Mahkamah Konstitusi Nomor 21/PUU-XII/2014 pada tahun 2014 diajukan oleh seorang karyawan PT. Chevron Pasific Indonesia yaitu Bachtiar Abdul Fatah yang mengajukan permohonan tertanggal 17 Februari 2014 berdasarkan Akta Penerimaan Berkas Permohonan Nomor 56/PAN.MK/2014 yang telah dicatat dalam buku registrasi dengan Nomor 21/PUU-XII/2014 yang telah diperbaiki dan diterima di Kepaniteraan Mahkamah pada tanggal 1 April 2014. ${ }^{10}$ Salah satu pasal tentang praperadilan yang dimohonkan pengujian dan diputus pada Putusan Nomor 21/PUU-XII/2014 adalah permohonan pengujian terhadap Pasal 77 huruf a KUHAP terhadap pasal 27 ayat (1), pasal 28D ayat (1) UUD 1945 yang dimohonkan untuk menyatakan pasal 77 huruf a KUHAP bertentangan dengan UUD 1945 secara bersyarat (conditionally unconstitutional) dan tidak mempunyai kekuatan hukum mengikat sepanjang tidak dimaknai mencakup sah atau tidaknya penetapan tersangka, penggeledahan, penyitaan, pemeriksaan surat. ${ }^{11}$

Dalam Putusan Mahkamah Konstitusi Nomor 21/PUU-XII/2014 ini, penulis tidak sependapat dengan dimasukkannya "Penetapan Tersangka" menjadi objek yang dapat diajukan sah atau tidaknya dalam praperadilan karena dengan beberapa pertimbangan. Pertama, hukum acara pidana di indonesia telah menganut asas praduga tidak bersalah yang sudah cukup melindungi hak asasi manusia tersangka atau terdakwa karena jika penetapan tersangka menjadi objek praperadilan maka setiap orang yang merasa penetapan tersangkanya tidak sah dapat

10 Mahkamah Konstitusi, Putusan Nomor 21/PUUXII/2014. hlm. 1-2.

${ }^{11}$ Ibid., hlm. 23. mengajukan praperadilan kepada pengadilan negeri sehingga hal ini akan menghambat proses hukum yang sedang berjalan sebagai upaya penyidik yang tidak hanya untuk melindungi kepentingan individu (tersangka atau terdakwa) tetapi juga untuk melindungi kepentingan publik. Kedua, pemeriksaan praperadilan tidak dapat disamakan dengan pemeriksaan pendahuluan sebagaimana dipraktekkan dalam negara-negara anglo saxon, karena tugas dan kewenangannya yang berbeda. Sehingga dalam pemeriksaan praperadilan tidak seharusnya memasukkan penetapan tersangka menjadi objek praperadilan karena pemeriksaan terhadap penetapan tersangka akan menyangkut alat bukti yang digunakan dalam menentukan keabsahan seorang tersebut tersangka atau tidak, padahal hal tersebut seharusnya dibuktikan pada pemeriksaan pokok perkara bukan pada pemeriksaan praperadilan. Dan juga pemeriksaan praperadilan seharusnya hanya menyangkut tentang hal yang bersifat formil bukan hal yang bersifat materil seperti sah atau tidaknya penetapan tersangka.

Dengan dua Putusan Mahkamah Konstitusi tersebut, praperadilan mengalami beberapa perkembangan, Yaitu dalam Putusan Mahkamah konstitusi Nomor 65 /PUU-IX/2011 kini menghapus keberadaan Pasal 83 ayat (2) KUHAP $^{12}$ yang bunyinya :

"Dikecualikan dari ketentuan ayat (1) adalah putusan praperadilan yang menetapkan tidak sahnya penghentian penyidikan atau penuntutan yang untuk itu dapat dimintakan putusan

\footnotetext{
${ }^{12}$ http://www.hukumonline.com/berita/baca/lt553f5575a cd85/mk-rombak-bukti-permulaan-dan-objek-praperadilan, diakses pada tanggal 6 April 2016 pukul 11.11 WITA.
} 
akhir ke pengadilan tinggi dalam daerah hukum yang bersangkutan".

$$
\text { Sehingga dalam }
$$
perkembangannya upaya banding dalam Putusan praperadilan tidak dapat diupayakan oleh pemohon maupun termohon dalam putusan praperadilan. Dalam putusan Mahkamah konstitusi Nomor 21/PUU-XII/2014, norma dalam Pasal 77 huruf a KUHAP bertambah. Sebelumnya, objek praperadilan hanya mencakup sah atau tidaknya penangkapan, penahanan, penghentian penyidikan, dan penghentian penuntutan. Dalam putusan ini menimbulkan objek penetapan tersangka, penggeledahan, dan penyitaan yang dilakukan oleh penyidik dapat dimohonkan sah atau tidaknya melalui praperadilan.

MK menegaskan, pada dasarnya setiap tindakan upaya paksa, seperti penangkapan, penggeledahan, penyitaan, penahanan, dan penuntutan yang dilakukan dengan melanggar peraturan perUndangUndangan adalah perampasan HAM, sehingga dengan adanya praperadilan diharapkan pemeriksaan perkara pidana dapat berjalan sesuai dengan peraturan hukum yang berlaku.

Pengawasan oleh pengadilan negeri (PN) sebagai badan peradilan tingkat pertama dimaksudkan untuk mengontrol, menilai, menguji, dan mempertimbangkan secara yuridis, apakah dalam tindakan upaya paksa terhadap tersangka/terdakwa oleh penyelidik/penyidik atau penuntut umum telah sesuai dengan KUHAP.

\section{Efektifitas praperadilan dalam sistem peradilan pidana anak di Indonesia}

Lembaga Praperadilan diatur di dalam Pasal 77 Undang-Undang Nomor 8

13 Bagir manan dalam AA. Oka Mahendra, Harmonisasi
Tahun 1981 tentang Kitab Undang-Undang Hukum Acara Pidana (KUHAP) sedangkan dalam Undang-Undang Nomor 11 Tahun 2012 tentang Sistem Peradilan Pidana Anak (SPPA) tidak mengatur tentang Lembaga Praperadilan secara khusus. Akan tetapi dalam BAB III "Acara Peradilan Pidana Anak" Bagian Kesatu "Umum" Pasal 16 Undang-Undang Nomor 11 Tahun 2012 tentang Sistem Peradilan Pidana Anak (SPPA) menentukan sebagai berikut :

"Ketentuan beracara dalam Hukum Acara Pidana berlaku juga dalam acara peradilan pidana anak, kecuali ditentukan lain dalam Undang-Undang ini”"

Ketentuan yang ada dalam Pasal tersebut menunjukkan bahwa hubungan antara KUHAP dengan SPPA dilandasi dengan adanya asas "Lex Specialis Derogat Legi Generalis" yang merupakan salah satu Asas Hukum, yang mengandung makna bahwa aturan hukum yang khusus akan mengesampingkan aturan hukum yang umum. Untuk dapat menggunakan asas ini ada beberapa prinsip yang harus diperhatikan, yaitu: ${ }^{13}$

1. Ketentuan-ketentuan yang didapati dalam aturan hukum umum tetap berlaku, kecuali yang diatur khusus dalam aturan hukum khusus tersebut;

2. Ketentuan-ketentuan lex specialis harus sederajat dengan ketentuan-ketentuan lex generalis (Undang-Undang dengan Undang-Undang);

3. Ketentuan-ketentuan lex specialis harus berada dalam lingkungan hukum (rezim) yang sama dengan lex generalis.

Sehingga kedudukan lembaga praperadilan dengan adanya asas Lex Specialis Derogat Legi Generalis memiliki kedudukan hukum umum karena tidak diatur secara khusus dalam SPPA mengenai lembaga praperadilan,

harmonisasi-peraturan-perundang-undangan.html diakses tanggal 15 April 2016. 
maka hubungan antara SPPA dengan KUHAP merupakan Lex Specialis Derogat Legi Generalis dari KUHAP. Dalam mengadili perkara anak penggunaan pengaturan Undang Undang SPPA didahulukan dari pengaturan yang diatur dalam KUHAP. Namun jika tidak diatur di dalam Undang Undang SPPA, baru digunakan pengaturan yang diatur dalam KUHAP yang merupakan ketentuan hukum umumnya. ${ }^{14} \mathrm{Jadi}$, Lembaga Praperadilan berlaku juga pada proses penyelesaian perkara tindak pidana anak karena tidak diatur secara khusus dalam SPPA.

Masalah penahanan merupakan masalah krusial di Indonesia. Setidaknya ada dua hal yang harus diperhatikan dalam UU SPPA terkait pengawasan dan mekanisme komplain terhadap upaya paksa penahanan. Pertama adalah perihal Pasal 9 Kovenan Internasional Hak Sipil dan Politik (Kovenan Sipol) dan mengenai mekanisme komplain yang harus dilembagakan. Keduanya tidak diatur dalam UU SPPA, merujuk kembali kepada Pasal 16 UU SPPA yang melegitimasi penggunaan KUHAP, maka perlu dilihat sejauh mana UU SPPA mampu secara efektf memberikan perlindungan terhadap hak anak. Setelah Indonesia meratifikasi Kovenan Sipol melalui UU No 12 Tahun 2005, maka secara langsung Indonesia tunduk pada ketentuan Pasal 9 Kovenan Sipol yang pada pokoknya mengatur bahwa jika penyidik melakukan penangkapan, maka dengan segera (promptly) harus membawa tersangka (secara fisik) ke hakim yang akan melakukan penahanan. Secara universal, promptly dimaknai selama 2 X 24 Jam (dua kali dua puluh empat) jam atau a couple of days. Tidak satupun ketentuan dalam UU SPPA yang merujuk pada ketentuan ini, padahal perubahan ini sudah dimulai dalam Rancangan KUHAP dengan menghadirkan Hakim Pemeriksa Pendahuluan. Mekanisme pengawasan upaya paksa penahanan dalam UU SPPA masih merujuk pada mekanisme pengawasan buruk milik KUHAP. Apabila merujuk pada Pasal 37 huruf d Konvensi Hak Anak, seharusnya setiap anak yang dirampas kemerdekaannya berhak untuk menggugat keabsahan perampasan kemerdekaannya di depan pengadilan atau pejabat lain yang berwenang, independen, dan tidak memihak, dan berhak untuk dengan segera memperoleh keputusan mengenai tindakan perampasan kemerdekaan tersebut. Meskipun tidak diatur secara tegas namun berdasarkan Pasal $16 \mathrm{UU}$ SPPA, berarti satu-satunya mekanisme komplain dan pengawasan terhadap upaya paksa penahanan yang dimiliki UU SPPA adalah melalui lembaga Praperadilan. Secara historis, maksud dan tujuan utama yang sebenarnya hendak ditegakkan dan dilindungi, dalam proses praperadilan adalah tegaknya hukum dan perlindungan hak asasi tersangka dalam tingkat pemeriksaan penyidikan dan penuntutan. Oleh karena itu dibentuklah lembaga praperadilan seperti yang diatur dalam Pasal 77 sampai dengan Pasal 83 KUHAP, guna kepentingan pengawasan terhadap perlindungan hal-hak tersangka dalam pemeriksaan pendahuluan. Kontrol tersebut dilakukan dengan caracara: (a) kontrol vertikal yaitu kontrol dari atas ke bawah; dan (b) kontrol horisontal, yaitu kontrol ke samping, antara penyidik, penuntut umum timbal balik dan tersangka, keluarganya atau pihak lain. Sepintas maka lembaga

14 Gatot Supramono, Hukum Acara Pengadilan Anak, Cet. 2, Ed. 1, Djambatan, Jakarta, 2005. hlm. 15. 
praperadilan seakan sudah mampu untuk melindungi kepentingan tersangka dan terdakwa terkhusus anak, namun berdasarkan penelitian yang dilakukan oleh ICJR, praperadilan dianggap bukan merupakan lembaga yang efektif sebagai mekanisme komplain terhadap penahanan. Sidang praperadilan cenderung terjebak dalam paradigma formalistik prosedural dari hakim, sehingga putusan-putusan yang dihasilkan tidak mencerminkan esensi praperadilan, yang harusnya menentukan efektivitas dari praperadilan itu sendiri.. Selain persoalan mendasar yang ada dalam praperadilan, secara hukum acara pun praperadilan nampaknya tidak sesuai dengan pengaturan yang ada dalam UU SPPA. Pasal 82 ayat (1) huruf c KUHAP berbunyi "pemeriksaan tersebut dilakukan cara cepat dan selambatlambatnya tujuh hari hakim harus sudah menjatuhkan putusannya", sebelumnya dalam Pasal 82 ayat (1) huruf a KUHAP berbunyi "dalam waktu tiga hari setelah diterimanya permintaan, hakim yang ditunjuk menetapkan hari sidang". Tafsir mulai kapan pasal 82 ayat (1) huruf c KUHAP ditempatkan, mengakibatkan dalam praktik pengadilan berkembang empat penafsiran yang berbeda-beda mengenai sejak kapan 7 hari tersebut dimulai; yakni pertama, perhitungan dimulai setelah perkara didaftarkan dan mendapat nomor registrasi di PN, kedua, perhitungan dimulai setelah ketua PN melakukan penunjukan hakim tunggal praperadilan, ketiga, perhitungan dimulai setelah hakim tunggal praperadilan membuka sidang perdana, dan keempat, perhitungan dimulai setelah para pihak lengkap. Berdasarkan penelitian ICJR, dari 80 perkara yang diobservasi paling banyak membutuhkan waktu beracara yang dapat diselesaikan dalam jangka waktu $1-7$ hari hanya 4 perkara, sementara jangka waktu pemeriksaan praperadilan umumnya diselesaikan dalam waktu melebihi 7 hari, dengan catatan yang dapat diselesaikan dalam jangka waktu 8-14 hari ada 16 perkara, lalu $15-21$ hari ada 35 perkara, 21-28 hari ada 15 perkara, 29-36 hari ada 7 perkara, dan 37- 45 hari ada 3 perkara. Masa penahanan anak dalam tahapan penyidikan dengan perpanjangan maksimal adalah 15 hari, sementara penahanan untuk anak dalam tahapan penuntutan adalah 10 hari, artinya masa dimana bisa diajukan praperadilan adalah total 25 hari dari mulai dilakukan penahanan. Melihat persesuaian antara waktu dapat diajukannya parperadilan dalam UU SPPA, dilihat dari masa penahanan, dengan fakta empiris waktu acara praperadilan, maka bisa dipastikan akan terjadi kendala serius dalam pengajuan praperadilan dalam kasus-kasus anak. Belum lagi fakta yang menunjukkan bahwa dengan menelisik proses pengajuan permohonan praperadilan, keberadaan advokat rupanya berpengaruh besar pada penggunaan mekanisme praperadilan. Situasi ini dapat dilihat dalam komposisi pengajuan permohonan praperadilan antara yang diwakili advokat dengan yang tidak. Melihat dari fakta tersebut, apabila disesuaikan dengan problem akses pada advokat dalam praktik peradilan anak, maka dapat dipastikan ketidakefektifan praperadilan juga akan terulang dalam praktik UU SPPA. Secara umum ini berarti bahwa kewenangan upaya paksa yang dimiliki oleh aparat negara tidak diimbangi dengan pengawasan dan mekanisme komplain yang baik, UU SPPA tidak berpijak dalam terkait kepentingan anak dalam perampasan kemerdekaan.

\section{PENUTUP}

\section{Kesimpulan}

a. Praperadilan dalam Sistem peradilan pidana anak adalah mekanisme 
complain yang diatur dalam UndangUndang namun secara factual sulit untuk dilaksanakan dikarenakan factor limit waktu penahanan dalam UU SPPA lebih cepat dari proses praperadilan yang masih mengaju pada KUHAP

b. kewenangan upaya paksa yang dimiliki oleh aparat negara tidak diimbangi dengan pengawasan dan mekanisme komplain yang baik, UU SPPA tidak berpijak dalam terkait kepentingan anak dalam perampasan kemerdekaan.

\section{Saran}

Diperlukan sebuah lembaga Praperadilan yang disesuaikan dengan limit waktu yang ada dalam UU SPPA sehingga sangat tepat apabila pengaturan tentang praperadilan dalam system peradilan pidana anak diatur secara khusus dalam UU SPPA

\section{DAFTAR PUSTAKA}

Beck, Elizabeth, et.al, In the Shadow of DeathRestorative Justice and Death Row Families, Oxford University Press, New York, 2007.

Hadisuprapto, Paulus. Peradilan Restoratif : Model Peradilan Anak Indonesia Masa Datang, Pidato Pengukuhan Guru Besar Fakultas Hukum Universitas Diponegoro, Semarang, 2006.

Herlina, Apong, et.al. Perlindungan Terhadap anak yang berkonflik dengan hukum, UNICEF, Jakarta, 2004.

Lintong Oloan Siahaan, Jalannya Peradilan Prancis Lebih Cepat dari Peradilan Kita,Ghalia Indonesia, Jakarta, 1981
Marshall, Tony F., Restorative Justice an Overview, The Home OfficeResearch Development and Statistics Directorate, London, 1999

Miers, David, An International Review ofRestorative JusticeHome OfficePolicing and Reducing Crime UnitResearch, Development and Statistics Directorate, London, 2001

Reichel, Philip L., Comparative Criminal Justice System, Prentice Hall, New Jersey, 2002.

Sudarto, Hukum dan Hukum Pidana, Bandung, Alumni, 1981,

Sudarto, Hukum Pidana dan Perkembangan Masyarakat, Bandung, Sinar Baru, 1983.

Soetodjo, Wagiati,Hukum Pidana Anak, Refika Aditama, Bandung, 2006.

United Nations, Handbook onRestorative Justice Programmes, New York, 2006.

Zulfa, Eva Achjani, Pergeseran Paradigma Pemidanaan di Indonesia, Jurnal Hukum \& Pembangunan Tahun ke-36 No 3 Juli-September 2006. 